\title{
Development and Characterization of Recombinant Inbreed Lines for Segregating Bacterial Wilt Disease in Tomato
}

\author{
Ambresh*, H.B Lingaiah, M. Renuka and B. Amruta Bhat \\ University of Horticultural Sciences, Bagalkot, Karnataka, India \\ *Corresponding author
}

\begin{tabular}{|c|c|}
\hline & A B S T R A C T \\
\hline & \multirow{6}{*}{$\begin{array}{l}\text { The present study was conducted at College of Horticulture, University of Horticultural } \\
\text { Sciences Campus, GKVK, Bengaluru during } 20014-15 \text {. The experimental material } \\
\text { comprised of bacterial wilt resistant variety, Anaga and susceptible variety, Vaibhav. The } \\
\text { seeds from } F_{1} \text { hybrid derived from the cross involving Anagha } x \text { and Vaibhav, were used } \\
\text { in a previous study at College of Horticulture, UHS Bengaluru, this cross combination was } \\
\text { identified for } F_{1} \text { being resistant and productive and a genetic analysis involving these two } \\
\text { parents also revealed monogenic/oligogenic nature of inheritance for bacterial wilt (Jyothi } \\
\text { et al., 2013) and All the } F_{2} \text { individual plants of Anaga } x \text { Vaibhav were advanced to } F_{3}, F_{4} \text {, } \\
F_{5} \text { and } F_{6} \text { generations following the Single Seed Descent (SSD) method for attaining } \\
\text { homozygous and heterogeneous RIL population. The experiment was laid out in } \\
\text { Randomized block design with three replication, further the } F_{6} \text { families of all the } \\
\text { individual plants were evaluated in sick plot conditions to ascertain their segregation } \\
\text { pattern for the incidence of bacterial wilt disease. Result on bacterial wilt showed that out } \\
\text { of } 300 \mathrm{~F}_{6} \text { populations } 61 \text { Recombinant inbreed lines were resistant and } 69 \text { were susceptible } \\
\text { for bacterial wilt disease incidence under sick field condition. }\end{array}$} \\
\hline Keywords & \\
\hline $\begin{array}{l}\text { Bacterial wilt, } \\
\text { Recombinant inbreed } \\
\text { lines. }\end{array}$ & \\
\hline Article Info & \\
\hline $\begin{array}{l}\text { Accepted: } \\
\text { 10 September } 2017 \\
\text { Available Online: } \\
10 \text { November } 2017\end{array}$ & \\
\hline & \\
\hline
\end{tabular}

\section{Introduction}

Tomato (Solanum lycopersicum Mill.) is an important and widely grown solanaceous vegetable crop around the world and belongs to the family solanaceae. It is native of Peru. It ranks second only after potato. In many countries it is considered as "poor man's orange" because of its attractive appearance and nutritive value (Singh et al., 2004). It is considered an important source of vitamin A, $\mathrm{C}$ and minerals (Hari, 1997). Apart from these, lycopene is valued for its anti-cancer property (Bose et al., 2002). It acts as an antioxidant and scavenger of free radicals, which is often associated with carcinogenesis. Thus, lycopene has got great beneficial effects on human health. It may also interfere with oxidative damage to DNA and lipoproteins and inhibits the oxidation of LDL (low density lipoprotein) cholesterol.

It remains in the focus of the horticultural industry ever since the mid nineteenth century. Tomatoes are being used in sandwiches, salads and processed products like paste, puree, soup, sauce, juice, ketchup, whole canned fruit and drinks (Bose et al., 2002). The fruits are mainly consumed either as raw or in the preparation of sambar, chatni, pickles etc. in our country. World-over, tomato cultivation spans over an area of 3.85 
million hectare, with a production of 130 million tonnes (FAO STAT, 2014). In India, tomato is cultivated in an area of 0.91 million hectare with an annual production of 18.82 million tonnes (Anon, 2014). In India its average productivity remains low at $21.3 \mathrm{t} / \mathrm{ha}$ as against $28.10 \mathrm{t} / \mathrm{ha}$ the world average (Anon, 2014).

Tomato is an annual and short lived perennial herbaceous plant. It is a typical day neutral plant and self-pollinated crop, but certain percentage of cross pollination also occurs. It is a warm season crop reasonably resistant to heat, drought and grows under wide range of soil and climatic conditions. Now, cultivation of tomato has become increasingly popular, since mid-nineteenth century. So far efforts of many vegetable breeders from both public and private sector have resulted in spectacular improvement in yield and quality characters. As a result of these efforts, hundreds of new cultivars have been developed since 50 years to meet the diverse needs and varied situations and climates under which tomato is grown. In the tropics, tomato productivity is comparatively low due to attack of several diseases caused by fungi, bacteria, virus and nematodes. Among them, the soil borne disease bacterial wilt Ralstonia solanacearum (Yabuuchi et al., 1995) is one of the most devastating and wide-spread diseases of crops worldwide (Poussier et al., 1999). The control of this disease is difficult because of the broad host range, wide spread in Karnataka, Kerala, Maharastra, Orissa and West Bengal. The loss in the yield is as high as 90.62 per cent. Sometimes it destroys the entire crop (Rao et al., 1975).

Ralstonia solanacearum (Smith) is soil borne bacterium which can survive up to three years in the soil. Even in the absence of any hosts. It is found up to $45 \mathrm{~cm}$ depth, concentrated near the rhizosphere, with the advancement of the disease. The disease spreads through infected plants materials, irrigation water, soil, farm implements etc. Sheltered sites include plants debris soil layers and the rhizosphere of the roots of weed hosts. Therefore it is difficult to advocate eradicate the disease, the only way is to concentrate on the development of hybrids that are resistant to disease. Symptoms of the disease include rapid and complete wilting of grown up plants. Pathogen is mostly confined to vascular region. Upon infection, bacterial polysaccharides mechanically block the vascular system, which checks the translocation of water and other food material resulting in wilting of plants.

Ralstonia solanacearum is an aerobic, nonsporing, gram-negative, soil borne plant pathogenic bacterium. It colonises in the xylem, causing bacterial wilt in a very wide range of potential host plants. Because of its devastating lethality, $R$. solanacearum is now of the more intensively studied phytopathogenic bacteria and bacterial wilt of tomato is a model system for investigating mechanisms of pathogenesis. It causes wilt disease in various crops and known to have several races. $R$. solanacearum infects more than 200 species in 50 families (Hayward, 1991), including tomato, potato, eggplant, pepper, tobacco, banana, chilli and peanut (French and Sequeira, 1970). The seedling mortality caused by bacterial wilt in tomato is the main problem in most of tropical regions (Jaw-Fen Wang et al., 2012).

\section{Materials and Methods}

The present investigation on "Development and characterization of recombinant inbreed lines for segregating bacterial wilt disease in tomato" was carried out during the years 2013-14 at College of Horticulture, University of Horticultural Sciences Campus, GKVK, Bengaluru The experimental site is situated at $13^{0}$ North latitude and $77.37^{\circ}$ East 
longitudes Eastern Dry Zone of Karnataka (Zone-5) The bacterial wilt resistant variety, Anaga and susceptible variety, Vaibhav (Table 1). The seeds from $F_{1}$ hybrid derived from the cross involving Anagha, bacterial wilt resistant variety released from Kerala Agricultural University and Vaibhav, a bacterial wilt susceptible variety released UAS, Bengaluru were used as starting material to develop recombinant inbred lines (RILs) segregating for bacterial wilt resistance. In a previous study at College of Horticulture, UHS Bengaluru, this cross combination was identified for $F_{1}$ being resistant and productive and a genetic analysis involving these two parents also revealed monogenic/oligogenic nature of inheritance (Jyothi et al., 2013). A population size of ca. 300 will be maintained starting from $F_{2}$ generation. The $\mathrm{F}_{2}$ lines were maintained at college of Horticulture Bangalore, by selfing $F_{1}$ of the cross Anagha $x$ Vaibhav. All the $F_{2}$ individual plants of Anaga $x$ Vaibhav were advanced to $F_{3}, F_{4}, F_{5}$ and $F_{6}$ generations following the Single Seed Descent (SSD) method for attaining homozygous and heterogeneous RIL population.

\section{Results and Discussion}

Bacterial wilt of tomato caused by Ralstonia solanacearum is a devastating soil borne disease in tropical, subtropical and humid regions of the world. High variability of strains of the pathogen (Elphinstone, 1992) combined with the influence of environment factors on host - pathogen interactions might be the reasons for the limited success in controlling this disease. Attempts to control this soil borne pathogen with different methods have so far proved ineffective; the use of resistant cultivars remains the best control strategy (Thurtson, 1976). A thorough knowledge regarding the pathogen, pathogenicity, source of resistance, inheritance of resistance becomes at most important to develop such stable resistant varieties or hybrids (Table 2).

Table.1 The experiment material used for present study

\begin{tabular}{|l|l|l|l|}
\hline S. No. & Variety & Source & Salient features \\
\hline 1 & Anaga & $\begin{array}{l}\text { KAU, } \\
\text { Thrissur }\end{array}$ & $\begin{array}{l}\text { Determinate growth habit, bacterial wilt } \\
\text { resistant variety with minimum average fruit } \\
\text { weight }\end{array}$ \\
\hline 2 & Vaibhav & $\begin{array}{l}\text { UAS, } \\
\text { Bengaluru }\end{array}$ & $\begin{array}{l}\text { Determinate growth habit, Bacterial wilt } \\
\text { susceptible variety }\end{array}$ \\
\hline 3 & $\begin{array}{l}\text { Anagha } \\
\text { Vaibhav }\left(\mathrm{F}_{2}\right)\end{array}$ & $\begin{array}{l}\mathrm{COH}, \\
\text { Bangalore }\end{array}$ & Resistant to Bacterial wilt $\left(\mathrm{F}_{1}\right)$ \\
\hline
\end{tabular}

Table.2 Mortality per cent and classification

\begin{tabular}{|l|l|}
\hline Per cent of disease incidence range & Reaction score \\
\hline $0-20 \%$ Plants wilted & Resistant \\
\hline $21-40 \%$ Plants wilted & Moderately resistant \\
\hline $41->80 \%$ Plants wilted & Susceptible \\
\hline
\end{tabular}


Table.3 Field reaction for Bacterial wilt disease score range of $\mathrm{F}_{2}: 3$ families of the cross Anagha x Vaibhav

\begin{tabular}{|c|c|c|}
\hline Per cent disease incidence range & Phenotype scored & Number of $\mathbf{F}_{\mathbf{2}}: \mathbf{3}$ families \\
\hline 1 to $20 \%$ of plant wilted & Resistant & 61 \\
\hline 21 to $40 \%$ of plant wilted & Moderately resistant & 170 \\
\hline 41 to $>80 \%$ of plant wilted & Susceptible & 69 \\
\hline & & Total = 300 \\
\hline
\end{tabular}

The genetic improvement of both quantitative and qualitative characters is the main interest of the plant breeder. The success of such a creative manipulation requires adequate knowledge of genetics of various characters. 300 recombinant inbreed lines (RILs) population were screened for bacterial wilt disease incidence at sick field condition out of 300 RILs population 61 were resistant, 170 and 69 were moderately resistant and susceptible respectively under field condition (Table 3). Data in table indicates that during 20013-14.

\section{References}

Anonymous. 2014. Indian Horticulture Database, National Horticulture Board, Gurgoan, pp 162

Bose, T. K., Bose, J., Kabir, T. K., Maity, V. A., Parthasarathy and Som, M. G., 2002, Vegetable Crops, Bhumani Mitra Publication, Calcutta, India.

French, E.R and Sequeira, L. 1970, Strains of Pseudomonas Solanacearum from Central America and South America a Comparative Study. Phytopathology, 60:3: 506.

Grimault, V., Prior, P. and Anais, G. 1995, A monogeneic dominant resistance of tomato to bacterial wilt I Hawaii 7996 is associated with plant colonization by Pseudomonas solancerum. J. Phyt. 143 (6):349-352.

Hari H. R., 1997, Vegetable Breeding Principles and Practices, Kalyani Publ. India.
Hayward, A.C. 1991, Biology and Epidemiology of Bacterial Wilt Caused by Pseudomonas solanacearum. Annu. Rev. Phytopathol. 29: 65-87.

Jaw- Fen Wang, Fang and Vanla dittapongpitch, 2012, Identification of major QTLs associated with stable resistance of tomato cultivar 'Hawaii 7996' to Ralstonia solanacearum. Euphytica, 190: 241-252.

Jyothi, k. 2013, Inheritance of bacterial wilt disease in tomato, Ph. D. Thesis, University of Horticultural Sciences, Bagalkot.

Kehnan, A. 1953, The bacterial wilt caused by Psedomonas solanacearum. N. C. Apro, Exposit. Tech. Bull. 99: 194.

Poussier, S., Vandewalle, P. Luisetti, J. 1999, Genetic Diversity of African and Worldwide Strains of Ralstonia Solanacearum as Determined by PcrRestriction Fragment Length Polymorphism Analysis of the Hrp Gene Region. Appl. Environ. Microbiol. 65:5: 2184-2194.

Rao, M. V. B, Sohi, H. S. and Tikoo, S. K., 1975, Reaction of wilt resistance tomato varieties and lines to Pseudomonas solanacearum in India. Pl. Dis. Rep., 59 : 734-736.

Singh, Nem Pal, Bharadwaj, A. K., Abnish Kumar and Singh K. M., 2004, Modern Technology on Vegetable Production, International Book Distribution Co. Lucknow, pp. 84- 98.

Yabuuchi E, Kosako Y, Yano I, Hotta H, Nishiuchi, Y 1995, Transfer of Two 
Burkholderia and an Alcaligenes Species to Ralstonia Gen. Nov.: Proposal of Ralstonia Pickettii (Ralston, Palleroni and Doudoroff 1973) Comb. Nov., Ralstonia Solanacearum (Smith 1896) Comb. Nov. And Ralstonia Eutropha (Davis 1969) Comb. Nov.
Microbiol. Immunol. 39(11): 897-904. Yang, C. Y. 1979, Bacterial and fungal diseases of tomato. Proc. 1st International Symposium on Tropical Tomato. R. Cowell (ed.) Asian Vegetable Research and Development Center. Shanhua, Taiwan. 188-200.

\section{How to cite this article:}

Ambresh, H.B Lingaiah, M. Renuka and Amruta Bhat, B. 2017. Development and Characterization of Recombinant Inbreed Lines for Segregating Bacterial Wilt Disease in Tomato. Int.J.Curr.Microbiol.App.Sci. 6(11): 1050-1054. doi: https://doi.org/10.20546/ijcmas.2017.611.122 